Article

\title{
Sustainable Building in China-A Green Leap Forward?
}

\author{
Richard C. Diamond ${ }^{1, *}$, Qing Ye ${ }^{2}$, Wei Feng ${ }^{1}$, Tao Yan ${ }^{2}$, Hongwei Mao ${ }^{2}$, Yutong Li ${ }^{2}$, \\ Yongcong Guo ${ }^{2}$ and Jialiang Wang ${ }^{2}$ \\ 1 Lawrence Berkeley National Laboratory, One Cyclotron Road, Berkeley, CA 94720, USA; \\ E-Mail: weifeng@lbl.gov \\ 2 Shenzhen Institute of Building Research, Futian District, Shenzhen 518049, China; \\ E-Mails: yeqing@ibrcn.com (Q.Y.); yant@ibrcn.com (T.Y.); maohw@ibrcn.com (H.M.); \\ liyutong@ibrcn.com (Y.L.); guoyc@ibrcn.com (Y.G.); wangjialiang@ibrcn.com (J.W.) \\ * Author to whom correspondence should be addressed; E-Mail: rcdiamond@lbl.gov; \\ Tel.: +1-510-486-4459; Fax: +1-510-486-6658.
}

Received: 17 July 2013; in revised form: 11 September 2013 / Accepted: 13 September 2013 / Published: 23 September 2013

\begin{abstract}
China is constructing new commercial buildings at an enormous rate-roughly 2 billion square meters per year, with considerable interest and activity in green design and construction. We review the context of commercial building design and construction in China, and look at a specific project as an example of a high performance, sustainable design, the Shenzhen Institute of Building Research (IBR). The IBR building incorporates over 40 sustainable technologies and strategies, including daylighting, natural ventilation, gray-water recycling, solar-energy generation, and highly efficient Heating Ventilation and Air Conditioning (HVAC) systems. We present measured data on the performance of the building, including detailed analysis by energy end use, water use, and occupant comfort and satisfaction. Total building energy consumption in 2011 was $1151 \mathrm{MWh}$, with an Energy Use Intensity (EUI) of $63 \mathrm{kWh} / \mathrm{m}^{2}\left(20 \mathrm{kBtu} / \mathrm{ft}^{2}\right)$, which is $61 \%$ of the mean EUI value of $103 \mathrm{kWh} / \mathrm{m}^{2}\left(33 \mathrm{kBtu} / \mathrm{ft}^{2}\right)$ for similar buildings in the region. We also comment on the unique design process, which incorporated passive strategies throughout the building, and has led to high occupant satisfaction with the natural ventilation, daylighting, and green patio work areas. Lastly we present thoughts on how the design philosophy of the IBR building can be a guide for low-energy design in different climate regions throughout China and elsewhere.
\end{abstract}


Keywords: China energy use; energy efficiency; commercial buildings; green design; sustainability

\section{Introduction}

In November 2012, at the 18th Congress of the Chinese Communist Party, China's President Hu Jintao described building a "beautiful China as the construction of ecological civilization" [1]. Two months later, reality replaced imagery as a thick and severe smog, blanketing almost all of China's east coast. In smog-choked Beijing, "peak readings for air pollution during the Chinese New Year were 40 times the World Health Organization's air-quality guidelines" [1]. There is perhaps no better demonstration of the urgent need to address China's environmental issues and green the economy. Is China ready and able to do so? We think so, and are encouraged by the nascent green building movement that is developing in China today.

\subsection{Impact of Buildings in China}

China is building new commercial buildings at an enormous rate-roughly 2 billion square meters per year, while the U.S. projected growth for the commercial building sector is roughly an order of magnitude lower, at 100 million square meters per year through 2030. The floor area for existing U.S. commercial buildings, 7.6 billion square meters, is slightly larger than the Chinese floor area for existing buildings, at roughly 7.1 billion square meters $[2,3]$.

Twenty percent of total primary energy consumption and carbon emissions in China come from the building sector. In 2008, the primary energy consumption of buildings in China was nearly 380 million tons of oil equivalent (excluding biomass energy), or a 1.5 fold increase relative to $1996[2,4]$.

The energy intensity (energy per unit of floor area) in buildings differs significantly across different climate zones. In China, the long winter heating period in the northern regions has led to a significant increase in energy use in the Hot Summer Cold Winter (HSCW) zone, while cooling energy use has skyrocketed in both the HSCW zone and the Hot Summer Warm Winter (HSWW) zones [2]. Energy intensity in buildings also differs significantly by building type. For example, electricity intensity in large public buildings ( $>20,000$ square meters) is often 2-3 times higher than that in smaller public buildings.

Carbon emissions associated with building energy use reached 1260 million tons in 2008. Both Chinese and foreign experts estimate that there exists "a huge potential for curtailing the increase in energy demand and greenhouse gas (GHG) emissions reduction by improving energy efficiency in China's building sector" [2].

\subsection{Status of Green Buildings in China}

In 2007, the Chinese Ministry of Housing and Urban-Rural Development (MOHURD) initiated a program entitled " 100 demonstration projects of green buildings and 100 demonstration projects of low-energy consumption buildings". Figure 1 shows the growth from the start of green building evaluation and labeling in China in 2008 to the conclusion of this initiative at the end of 2011. During this period, a total of 271 buildings were awarded with a green building evaluation label [2]. 
Figure 1. Number of Green Commercial Building Projects in China, 2008-2011. Source: [2].

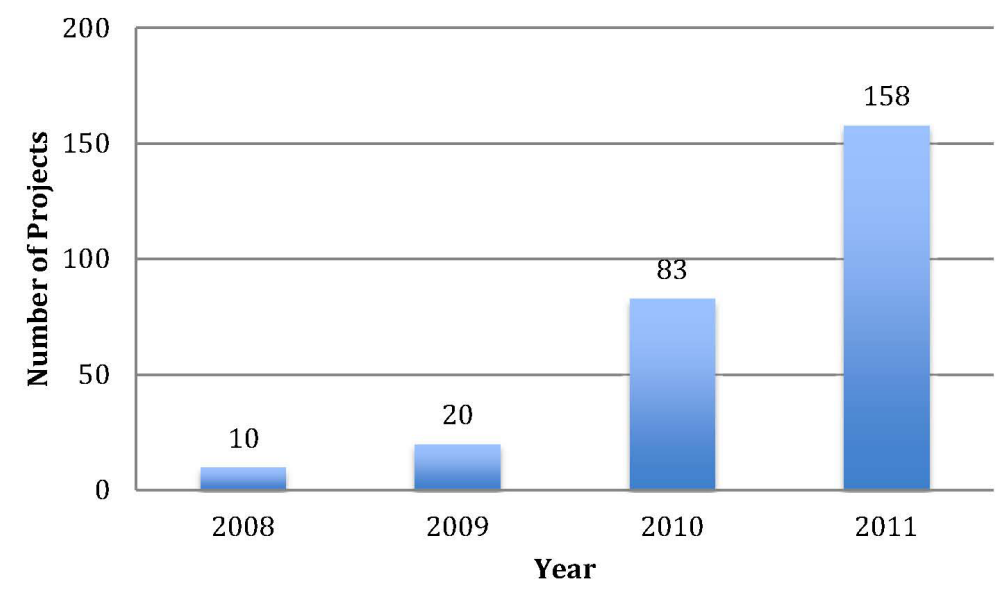

By December 2010, the "projects in China that received green building certificates had a construction floor area of 1.3 million square meters. China has targeted more than $80 \%$ of government invested new public construction needs to be green buildings by the end of the 12th Five Year Plan in 2015" [2].

\section{Designing the IBR Building}

The Shenzhen Institute of Building Research (IBR) designed its new headquarters "as a green experiment" [5]. As both the architect and client for the project, the design team could pursue a green agenda beyond what their counterparts were doing in China and elsewhere. The team reviewed over 100 sustainable technologies and strategies, and incorporated forty of them, including daylighting, natural ventilation, gray-water recycling, solar-energy generation, and highly efficient Heating Ventilation and Air Conditioning (HVAC) systems. The resulting building is 12 stories high and $18,000 \mathrm{~m}^{2}$ in floor area. The building was designed between the years 2006 and 2007, with construction completed in March 2009.

According to the building design team, "the IBR design team implemented the green design principals of localization, low-energy consumption, and finely detailed design". The designers wanted the IBR headquarters to "showcase the best sustainable building practices, while differentiating it from other expensive technology performance green buildings that were being built in Chinese cities" [5]. The designers of the IBR Building had the goal "of a fully sustainable building, one that would use resources wisely, provide a comfortable work environment, and serve as a model for others interested in designing low-energy buildings" [5].

Figure 2 shows the schematic diagram for green building design that was used for the IBR. The design for a green building starts with the three elements at the center of the diagram: people, resources, and the environment. To serve these three core elements, the design was carried out to meet six criteria shown in the next ring: land savings, water savings and use of natural water resources, good indoor air quality, energy efficiency and renewable energy harvest, materials savings and natural materials utilization, and good operation and management. To achieve these goals, the building design considers the elements in the final ring: climate, economy, policies, culture, technology, and management. 
Figure 2. Concept of green building design.

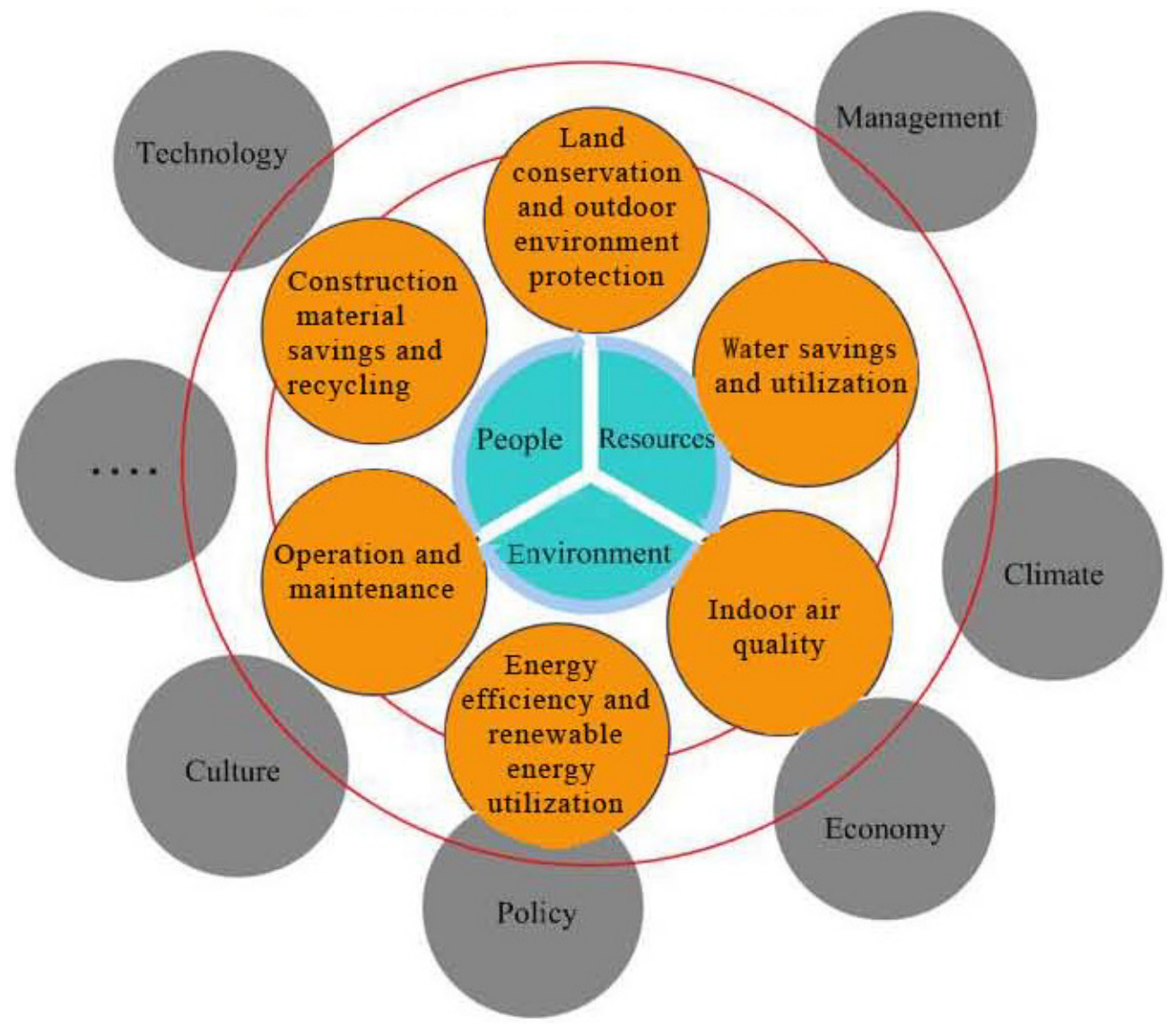

\subsection{Climate and Design}

China is divided into a diverse set of climate zones, ranging from "severe cold" in the North and Western plateaus, to the "Hot Summer/Warm Winter" (HSWW) in the South (Figure 3). Shenzhen is located in the HSWW zone, and has mean monthly winter temperatures generally above $10{ }^{\circ} \mathrm{C}(50 \mathrm{~F})$ and mean monthly summer temperatures in the range of $18-25^{\circ} \mathrm{C}$.

Figure 3. Climate zones in China. Shenzhen is located in the Hot Summer Warm Winter Zone. Source: Huang and Deringer (2007) and MOHURD (1993) [2].

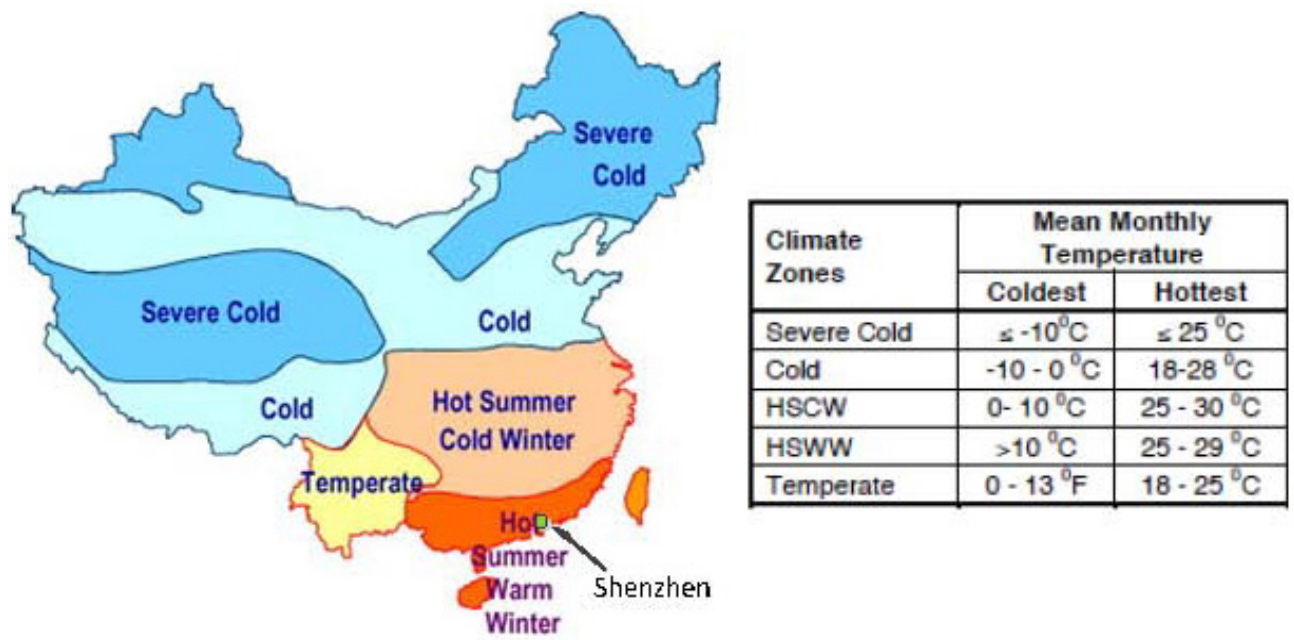


Climate is one of the most important factors in determining the energy use in a commercial building. The IBR design team worked closely with the local climate features to minimize the amount of energy needed to condition and illuminate the workspaces. Their climate strategies included working with sunlight for passive heating and shading the envelope to reduce overheating, often using PV materials to take advantage of the incident sunlight.

\subsection{Sustainable Strategies for the IBR Building}

The IBR design team started with the passive principles suitable for their hot-summer and warm-winter regional climate. They then took the strategy of integrated design, through the selection of the best technologies and coordination of multiple systems. They did multiple simulations and applications with their Building Information Modeling (BIM) models to arrive at optimal strategies. The result was a systems analysis that led to their novel layout of the building, including structural design, and functional zoning.

\subsubsection{HVAC System and Zoning}

The IBR building has different HVAC systems to accommodate the building's different cooling needs. The basement and 1st floor use a water source heat pump (WSHP). The heat pump is located close to the landscape water pool, so the close-loop condenser water exchanges heat directly with the water pool, which further reduces condenser water temperature and increases the WSHP system efficiency.

The rest of the floors use high chilled water supply temperature chillers $\left(18{ }^{\circ} \mathrm{C} \mathrm{CHW}\right.$ supply temperature), with solution-based, dehumidification air-handling units, and fan coil units. Since the CHW temperature is high, the fan-coil units just condition the building's sensible heat load, which avoids condensing moisture and saves energy used for latent heat. Solution-based dehumidification air-handling units are used to control the indoor relative humidity. This system not only controls sensible and latent heat separately, thereby saving energy, but also provides good indoor thermal comfort.

The building is zoned to have relatively smaller AC zones. The intent was to try to use natural ventilation to meet occupants thermal comforts whenever possible, and thereby reduce AC operating hours. For example, the balconies, hot water rooms, restrooms and elevator rooms do not have AC and rely entirely on natural ventilation.

\subsubsection{Natural Ventilation}

The building is designed with horizontally pivoted windows to control the natural ventilation and direct the airflow above the work surfaces. The designers modeled the natural ventilation using computational fluid dynamics (CFD) that showed that pivoted windows could provide better natural ventilation than other traditional window designs.

\subsubsection{Hot Water System}

Solar thermal collectors are installed on the building's rooftop. The collected hot water is used for the building's cafe and shower rooms. It is estimated that the solar thermal system can produce hot water at around 4350 tons per year, with energy savings of 91.2 tons of coal equivalent per year. 


\subsubsection{Lighting}

The building uses LED lights for its outdoor lighting, primarily for the building's signage on its west and south side. Daylight tubes are installed in the basement garage, providing $100 \%$ of the daytime lighting needs. The building integrates daylighting throughout the office spaces, which controls indoor lighting fixtures based on the lighting from the outdoor environment.

\subsubsection{Building Envelope}

The IBR building uses low-E double-paned windows with frames made from an aluminum alloy, for good daylight, thermal, acoustic and anti-freezing performance. Based on the IBR specifications, the windows have a visible light transmittance (VT) of 0.45 , shading coefficient (SC) of 0.4 , a thermal conduction coefficient $(\mathrm{K})$ of $2.0 \mathrm{~W} / \mathrm{m}^{2} \mathrm{~K}$, and acoustic isolation performance of $60 \mathrm{~dB}(\mathrm{~A})$.

Different window to wall ratio (WWR) numbers are used for different areas of the building. The lower areas of the building are mainly designed for labs and conference rooms, where a WWR value of 0.3 was used for the South, East and North elevations to minimize daylight impact on lab testing and conference space. The upper part of the building is used for office space, where a WWR value of 0.7 was chosen to make use of daylight and reduce artificial lighting energy consumption.

Shading is important for buildings located in Hot Summer Warm Winter (HSWW) climate region in China, and the IBR building adopted different shading strategies for different elevations. Overhangs with interior screens are used for office rooms. Vegetation is planted to cover parts of the building's west side facade. The opaque part of building envelope applies insulation materials and aluminum exterior finishing on cast concrete, which makes the building envelope easy to clean and maintains good thermal integrity. The west side of the building facade is integrated with thin film PV. The PV-integrated facade has a visible transmittance of 0.2 , which maintains acceptable visibility and harvests renewable energy for the building.

The design team considered several other green design features that did not make it into the final design. Technologies that were considered but didn't get used included adjustable exterior shades and a greater use of recyclable building material.

\subsubsection{Building Massing and Integration}

The architects designed the building as a set of "building blocks" explains IBR Dean Qing Ye. "The three-dimensional stacked functions are the unique aspects of the building". By organizing portions of the building into various blocks and stacking them, the architects were able to create a 12-story outdoor atrium on the east side that captures southeasterly breezes and brings daylight deep inside (Figure 4). Photovoltaic panels covering the atrium provide clean energy as part of China's first state-level renewable energy demonstration project [5]. 
Figure 4. Shenzhen Institute of Building Research (IBR) building floor plan (7-12 floors).

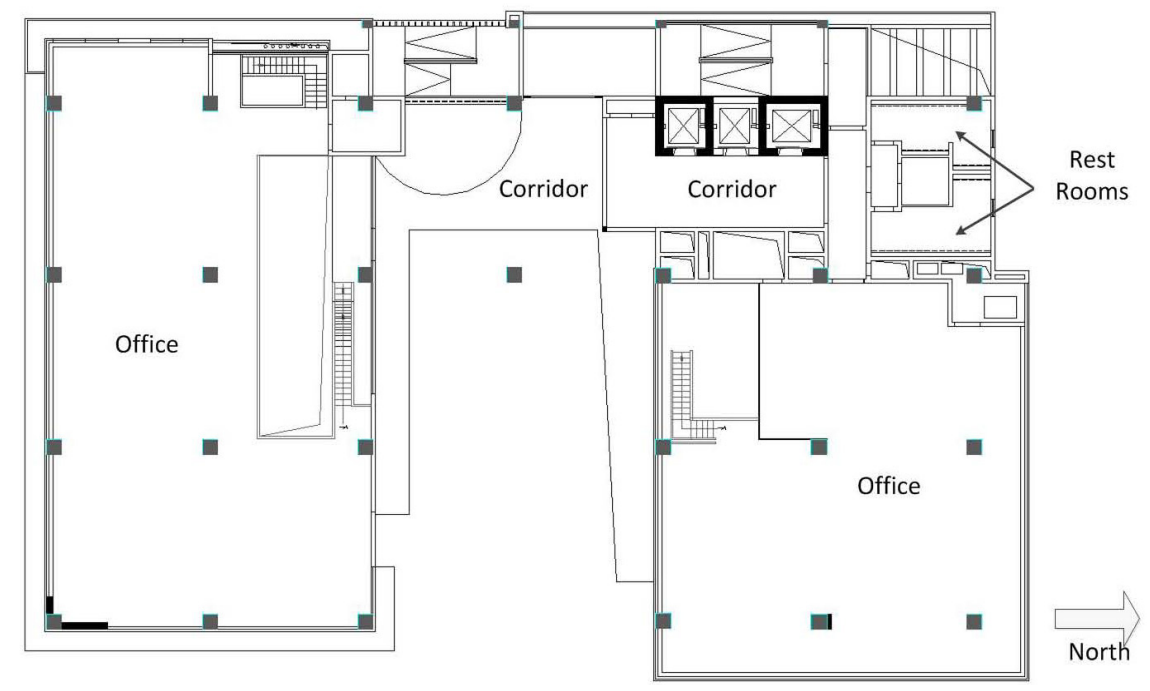

\subsection{Building Costs and Savings}

The architects kept the total per-square-meter construction cost to RMB $4300 \mathrm{Yuan} / \mathrm{m}^{2}\left(\$ 700 / \mathrm{m}^{2}\right.$ or $\$ 70 / \mathrm{ft}^{2}$ ), which is a remarkably low number considering all of the sustainable measures included in the project. Because the design was done in-house, they did not track the design costs, or the incremental costs for the sustainable design features. We do have data for two new green "3-Star" buildings in Shenzhen, and the incremental costs for the green measures were $376 \mathrm{RMB} / \mathrm{m}^{2}$ and $254 \mathrm{RMB} / \mathrm{m}^{2}$ for "2-star" green buildings.

According to the IBR, the average cost for high-end, new commercial office buildings in Shenzhen is between RMB 6000 and 8000 Yuan $/ \mathrm{m}^{2}$ ( $\$ 950$ to $\$ 1270$ per $\mathrm{m}^{2}$ or $\$ 88$ to $\$ 118$ per $\mathrm{ft}^{2}$ ). For middle level new buildings in Shenzhen, the average cost is between RMB 4000 and $6000 \mathrm{Yuan} / \mathrm{m}^{2}$ ( $\$ 635$ to $\$ 950$ per $\mathrm{m}^{2}$ or $\$ 59$ to $\$ 88$ per $\mathrm{ft}^{2}$ ). There are a few reasons for how the IBR building was able to achieve low cost construction. One is the "design-build" model, where IBR managed the entire building's design, construction and operation stages through an integrated approach. Another reason is the simple interior design and finishes. We don't have the results of the energy model to compare a "standard" building with the IRB building, but the IBR has reported that the building reduces annual electricity costs by 15 million RMB ( $\$ 2.4$ million/year), water costs by 54,000 RMB (\$8800/year), and carbon dioxide emissions by 1600 tons per year.

\section{Building Performance}

There are many ways to evaluate the performance of a green building over the course of a year. Does the building meet the expectations of the owner? Do the systems perform as expected? Are the energy targets met? Are the occupants satisfied with their work environments? The IBR was designed to be a living laboratory — some systems were designed to be experimental, others were designed to be dynamic and change over time. As a work in progress, the building and its evaluation continue to evolve as we learn what works and can be applied to new projects. 


\subsection{Whole Building Energy Consumption}

Perhaps the most straightforward performance indicator is the energy use of the building. In this paper we define the energy use as being the "operational" energy used by the building, that is, the energy used for space conditioning, lighting, water heating, appliances and equipment. We are not using the "total life cycle" definition, which includes the energy used in the production and transport of building materials, construction, operation, and demolition. Both definitions are used in Chinese research reports, and government documents, so it is important to be clear on which definition is being used, especially when making comparisons between buildings. Also, we further define the operational energy as the "site" energy, that is, the energy measured by the meter at the site. So in the case of electricity, we are showing the energy consumed at the "site" and not at the power plant.

Table 1 shows the total annual whole building energy consumption. In 2011 the IBR had a total energy consumption of 1,151,033 $\mathrm{kWh} /$ year, with an Energy Use Intensity (EUI) of $63 \mathrm{kWh} / \mathrm{m}^{2}$ $\left(20 \mathrm{kBtu} / \mathrm{ft}^{2}\right), 84 \%$ of which came from the city grid. Roughly 10 percent of the energy used in the building was supplied by city gas mains.

Table 1. Annual whole building energy consumption by fuel (2011).

\begin{tabular}{cccc}
\hline \multicolumn{2}{c}{ Energy Source } & $\mathbf{2 0 1 1}(\mathbf{k W h} / \mathbf{y e a r})$ & Percent \\
\hline \multirow{3}{*}{ Source } & Total consumption & $1,151,033$ & $100 \%$ \\
& City grid & 966,567 & $84 \%$ \\
& Photovoltaic & 69,555 & $6 \%$ \\
& Gas equivalent value & 114,911 & $10 \%$ \\
\hline
\end{tabular}

\section{Self-Generated Electricity}

The IBR has a variety of different solar panel types, ranging from mono-silicon PV modules to translucent amorphous modules, plus a standard solar hot water array. These different technologies were chosen to demonstrate different applications of building-integrated-PV. The translucent amorphous PV was used on the west elevation to allow daylighting as well as shading. Table 2 shows the type and area for the different solar panels at the IBR.

Table 2. Solar panel types and areas at the IBR.

\begin{tabular}{ccc}
\hline Panel Type & Module Type & Area $\left(\mathbf{m}^{\mathbf{2}}\right)$ \\
\hline & Mono-silicon PV module & 136 \\
Photovoltaic & Poly-silicon PV module & 134 \\
& HIT PV module & 125 \\
& Translucent Amorphous PV module & 600 \\
\hline Solar hot water & Copper and aluminum composite flat plate collector & 268 \\
\hline & Total & 1263 \\
\hline
\end{tabular}

Electricity generated by the IBR's photovoltaic array was $69,555 \mathrm{kWh}$ in 2011 accounting for $6 \%$ of the building's total energy use and 7\% of the building's total electricity use. Figure 5 shows the monthly electricity generation at the IBR, ranging from a monthly low of $3147 \mathrm{kWh} / \mathrm{month}$ in January, to a high of $7920 \mathrm{kWh} / \mathrm{month}$ in August. 
Figure 5. Electricity generated at the Shenzhen IBR (2011).

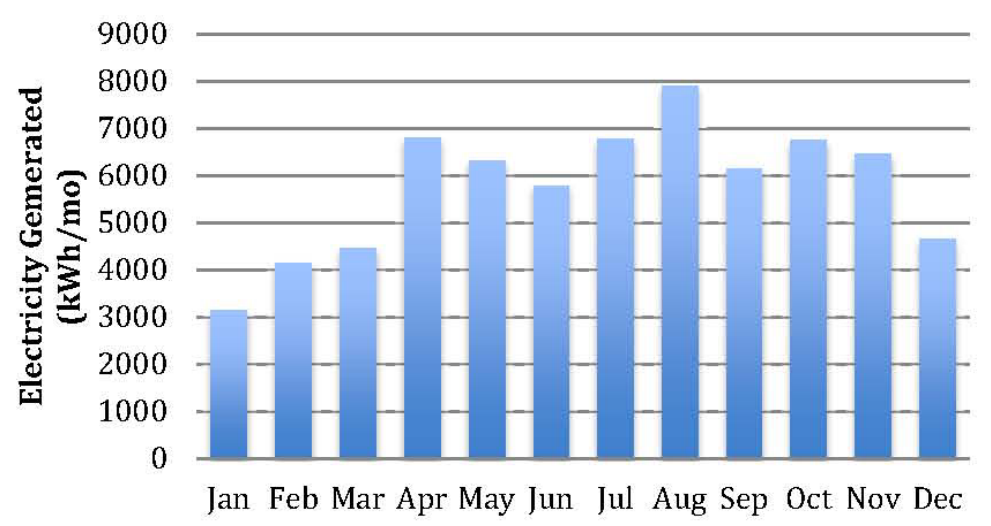

2011

\subsection{End Use Energy Use}

The distribution of energy use in the IBR building on an annual basis is shown in Figure 6 and in Table 3. The largest end use $(36 \%)$ is the electricity to run the servers and other IT equipment. The next largest is Air Conditioning (21\%) followed by "Other" (18\%) which includes the laboratory spaces, apartments, showers, exhibition center and elevated floors, and "Lighting and Plug Loads" (16\%). The "Mechanical Systems" account for only $8 \%$ of the total energy.

Figure 6. Shenzhen IBR annual energy end uses (2012).

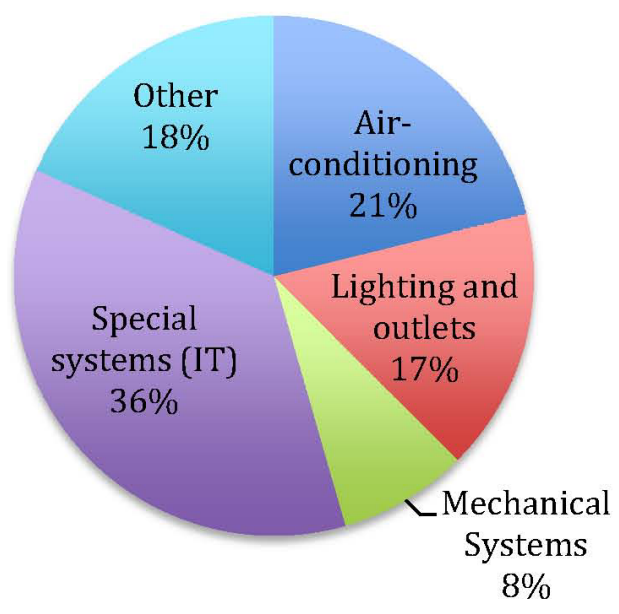

Table 3. Annual end uses: cooling, lighting and plug loads, mechanical, and IT systems.

\begin{tabular}{cccc}
\hline End Use & $\mathbf{k W h} / \mathbf{y e a r}$ & $\mathbf{k W h} / \mathbf{m}^{\mathbf{2}}$-year & Percent of Total \\
\hline Air-conditioning & 243,533 & 14 & $21 \%$ \\
Lighting and outlets & 188,127 & 10 & $17 \%$ \\
Mechanical systems & 92,759 & 5 & $8 \%$ \\
Special systems (IT) & 415,481 & 23 & $36 \%$ \\
Others & 211,133 & 12 & $18 \%$ \\
\hline Total & $1,151,033$ & 63 & $100 \%$ \\
\hline
\end{tabular}

Notes: Others include laboratory, apartment, shower, exhibition center and elevated floors. 
Another way to look at the energy end use breakdown is in the weekly profiles during different seasons. We examined a typical week's energy end use data in four different months. Figure 7 shows that in August, air-conditioning (AC) consumes large amount of electricity during weekdays. Typically, AC is turned on from 8:15 am, 15 min prior to the building's work hour, and turned off after 6:00 pm. There is nearly no AC energy use during non-work hours, which demonstrates the building is operated very efficiently when it is not occupied. In non-AC seasons, November and February, data center and plug dominate the building's energy use.

Figure 7. Typical weekly electricity end use in August.

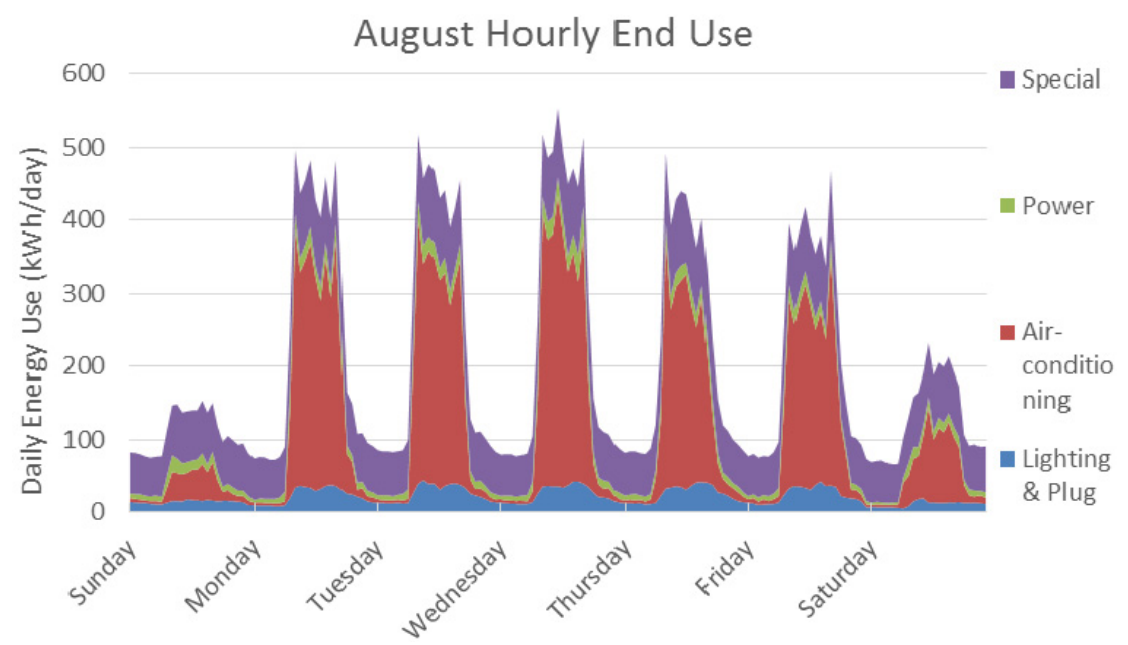

To further understand how the building is operated, we take the peak hourly electricity use and the base electricity load and calculate the peak-to-base energy use ratio. In May and August, the peak-base load ratio factor is 5.00 and 5.96 respectively. This is caused by the large AC electricity energy use and good AC operation management strategy. However, during non-AC seasons, the factor is only 2.6 and 2.7 because of the large electricity load from the data center, which runs continuously.

\subsubsection{Air Conditioning Use}

The IBR Building was predicted to use $33 \mathrm{kWh} / \mathrm{m}^{2}$ for air conditioning, but the actual AC energy usage in 2011 was $17 \mathrm{kWh} / \mathrm{m}^{2}$, nearly half the predicted usage. The likely reason for this difference is that the predicted AC energy is calculated based on the Chinese commercial design standard that assumes a fully air conditioned building. However, the IBR building uses natural ventilation to reduce AC energy usage whenever possible, while still maintaining comfort conditions. We look at the IBR air conditioning use compared to other similar office buildings in Shenzhen in a later section.

\subsubsection{Plug Loads and Lighting}

The IBR was designed to maximize use of daylighting and to have lights and plug loads turned off on weekends and periods of little occupancy. The only data that separates the plug loads and lighting was metered on the eighth floor. Figure 8 shows the power use for the plug loads and lighting for one week in August 2011 on the eighth floor offices. 
Figure 8. Power use for Plug Loads (red) and Lights (blue) for one week (1-7 August 2011) from the 8th floor offices of the IBR Building.

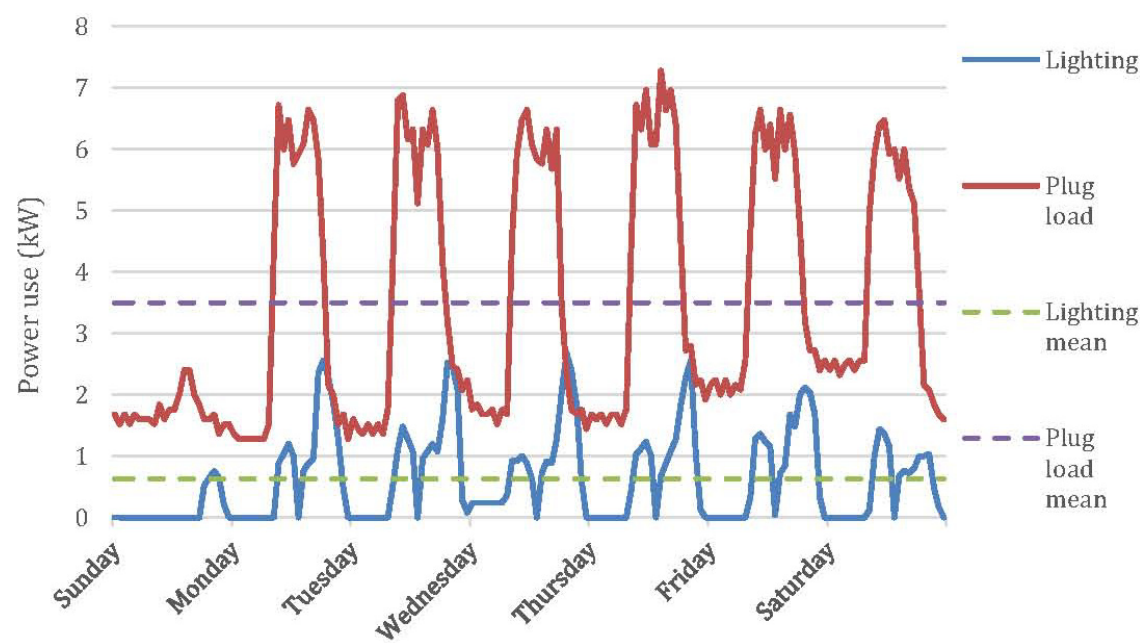

The mean value for the lighting power during this week was $0.63 \mathrm{~kW}$, with a peak value of $2.7 \mathrm{~kW}$. The mean value for the plug load power during this week was $3.5 \mathrm{~kW}$, with a peak value of $7.3 \mathrm{~kW}$. Figure 8 shows that the lighting loads are at or near zero for these unoccupied periods. Unlike typical practice in the U.S., janitorial work at the IBR is done during the workday, so crews don't need to have lights on at night to do their work. The plug loads also show a high degree of control, in that they are mostly off at night and weekends, but unlike lighting, there is a $1-2 \mathrm{~kW}$ base load value during the week, due primarily to constant loads of the data center.

Looking at the lighting power intensity, Figure 9, we see a mean value of $0.4 \mathrm{~W} / \mathrm{m}^{2}$ and a peak value of $1.7 \mathrm{~W} / \mathrm{m}^{2}$ for the lighting loads. Perhaps the best value to reflect the low lighting power intensity is the mean lighting load on weekdays during the work period of 9:00 to 18:00, which is $0.7 \mathrm{~W} / \mathrm{m}^{2}$. For comparison, the Chinese standard for lighting design is $11 \mathrm{~W} / \mathrm{m}^{2}\left(1.1 \mathrm{~W} / \mathrm{ft}^{2}\right)$, which is slightly higher than the U.S. lighting standard of 0.9 W/ $\mathrm{ft}^{2}$ in ASHRAE 90.1-2010 [6]. Clearly, the Shenzhen IBR is taking maximum advantage of available daylight during work hours, and is shutting off lights at night, lunch time and Sundays.

Figure 9. Power Use Intensity for Plug Loads (red) and Lights (blue) for one week (1-7 August 2011) from the 8th floor offices of the IBR Building.

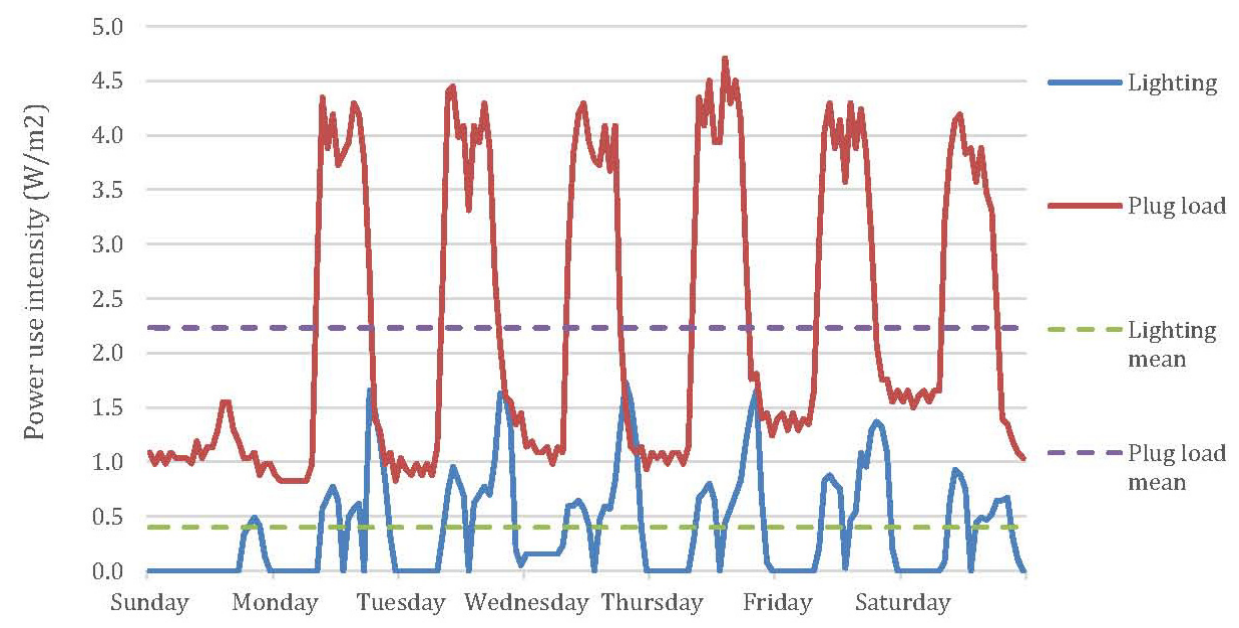


Looking at the plug load power intensity in Figure 9, we see a mean value of $2.2 \mathrm{~W} / \mathrm{m}^{2}$ and a peak value of $4.7 \mathrm{~W} / \mathrm{m}^{2}$ for the plug loads. Perhaps the best value to reflect the plug load power intensity is the mean plug load on weekdays during the work period of 9:00 to $18: 00$, which is $3.9 \mathrm{~W} / \mathrm{m}^{2}$. For comparison, the Chinese standard for plug load design is $20 \mathrm{~W} / \mathrm{m}^{2}$, which is higher than the U.S. plug load standard reference value of $7 \mathrm{~W} / \mathrm{m}^{2}$ for compliance with American Society of Heating, Refrigerating and Air Conditioning Engineers (ASHRAE) 90.1 (2010).

\subsection{Comparison with Other Buildings}

How does the IBR building compare to other buildings in China and the U.S. in energy use? And how does the IBR compare with other green buildings? We have a few benchmarks for comparison.

Figure 10 shows the annual energy use intensities (EUI) for 57 large office buildings in the city of Shenzhen. These buildings have similar function, operation hours and occupant density as the Shenzhen IBR. The EUIs for these buildings range from 50 to $200 \mathrm{kWh} / \mathrm{m}^{2}$. The mean value is $103 \mathrm{kWh} / \mathrm{m}^{2} /$ year and the median value is $96 \mathrm{kWh} / \mathrm{m}^{2} /$ year. The EUI of the IBR $\left(63 \mathrm{kWh} / \mathrm{m}^{2}\right)$ is one of the lowest in the sample, due in part to its use of natural ventilation and daylighting. We suspect that the three buildings in the sample with a lower EUI have only partial occupancy, or a much lower server equipment load.

Figure 10. Energy Use Intensity (EUI) for 57 Shenzhen office buildings.

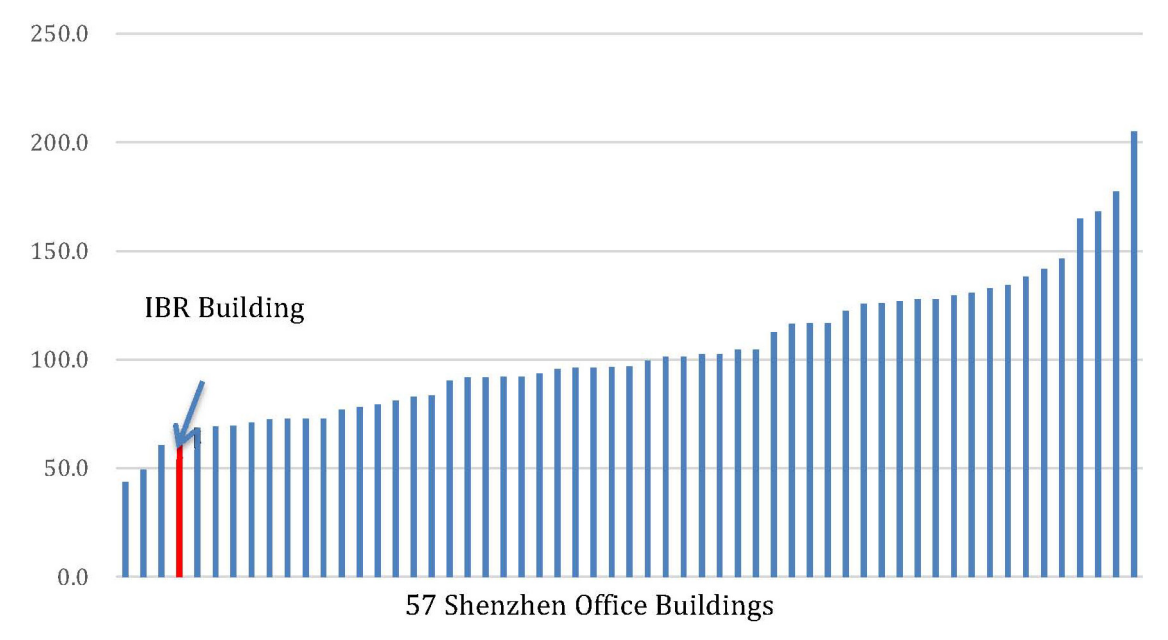

Another benchmark for comparison is the Chinese building energy data reported by the Building Energy Efficiency Research Center (BEERC) at Tsinghua University. In the BEERC Research Report on Annual Development of Building Energy Efficiency in China [7], they report average EUIs for large (over 20,000 $\mathrm{m}^{2}$ ) commercial buildings in the range of $90-200 \mathrm{kWh} / \mathrm{m}^{2}$ similar to the range for the Shenzhen commercial buildings shown in Figure 10. Looking at the end use intensities for a sample of 14 of these 57 buildings for which we have the end use breakdown, the mean annual air conditioning load is $36 \mathrm{kWh} / \mathrm{m}^{2}$ with a range of 17 to $91 \mathrm{kWh} / \mathrm{m}^{2}$. The mean lighting and plug load value is $53 \mathrm{kWh} / \mathrm{m}^{2}$-year with a range of $23-82 \mathrm{kWh} / \mathrm{m}^{2}$-year from a sample of 35 buildings. Not surprisingly, the Shenzhen IBR values are at the low end for these end uses.

In the U.S., we have two references for comparison with other buildings. The first reference is the U.S. Energy Information Administration, which collects information of a weighted statistical sample of 
commercial buildings, the Commercial Building Energy Consumption Survey [3]. The most current data are from the 2003 survey. The average energy use intensity (energy per square foot) for U.S. commercial buildings from 1990 to 2003 was $88 \mathrm{kBtu} / \mathrm{ft}^{2}$. The Shenzhen IBR Building has an annual EUI of less than $25 \%$ of U.S. commercial buildings at, of $63 \mathrm{kWh} / \mathrm{m}^{2}\left(20 \mathrm{kBtu} / \mathrm{ft}^{2}\right)$.

The second references for comparison are a set of 22 green federal buildings in the US that were recently studied [8]. The mean energy use intensity for these groups of green office buildings was $66 \mathrm{kBtu} / \mathrm{ft}^{2}$, which was $25 \%$ lower than the average for US office buildings. But the Shenzhen IBR at $20 \mathrm{kBtu} / \mathrm{ft}^{2}$ is still using less than a third of the energy use of these U.S. green buildings.

\subsection{Water Use}

Commercial buildings use $12 \%$ of the potable water in the U.S. The potable water use data often includes a combination of water use for drinking, bathing, cooking, landscape water use, and sometimes, process water use.

The Shenzhen IBR uses roughly 11,000 cubic meters ( 3 million gallons) of water per year. Table 4 shows the split between city water and rain water used for irrigation and other uses. Roughly $40 \%$ of the building's water use is from reclaimed rain water.

Table 4. Annual whole building water consumption in 2011 by source.

\begin{tabular}{ccc}
\hline Source & Volume $\left(\mathbf{m}^{\mathbf{3}} /\right.$ year) & Volume (gallons/year) \\
\hline City water & 6583 & $1,737,912$ \\
Captured rain water & 4699 & $1,240,536$ \\
Total consumption & 11,282 & $2,978,448$ \\
\hline
\end{tabular}

Figure 11 shows the seasonal variation in water use, by source. Gray water does not show much seasonal variation, but tap water use is higher in both the winter and the summer months, and we do not know why.

Table 5 shows the annual water consumption by end use (domestic, landscaping, cooking, and cooling). The largest end use is domestic water used for cleaning, showering, and drinking. Landscaping uses little city water due to the use of rainwater.

Figure 11. Shenzhen IBR monthly water consumption (2011).

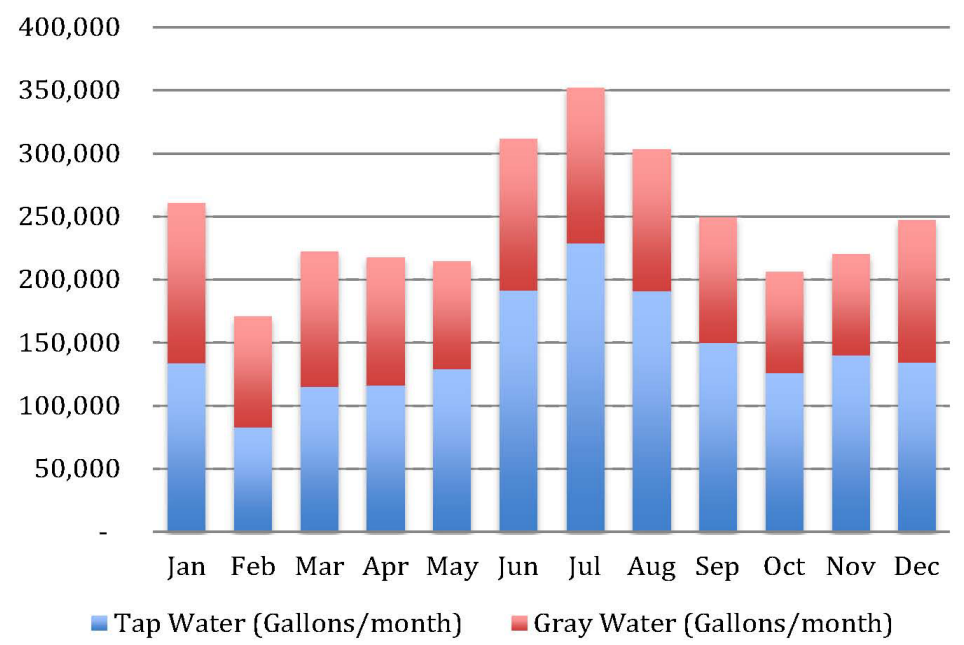


Table 5. Annual water consumption by end uses (cooling, landscaping, etc.) for 2011.

\begin{tabular}{cccc}
\hline End Use & Volume $\left(\mathbf{m}^{\mathbf{3}} /\right.$ year) & Volume (gallons/year) & Volume (gallons/ $\mathbf{m}^{2}$-year) \\
\hline Domestic water & 8013 & $2,115,432$ & 106 \\
Landscape water & 803 & 211,992 & 11 \\
Cooking water & 2405 & 634,920 & 32 \\
Air conditioning replenishment & 60 & 15,840 & 1 \\
Total water consumption & 11282 & $2,978,448$ & 150 \\
\hline
\end{tabular}

How does the water consumption at the IBR building compare to other green buildings in China and the U.S.? We have a few points of reference for comparison. In the U.S., we have two references, the International Facility Management Association (IFMA) has a 50th percentile reference of 15 gallons $/ \mathrm{ft}^{2}$-year (150 gallons $/ \mathrm{m}^{2}$-year) [9], and the U.S. General Services Administration has a 2015 target of 13 gallons $/ \mathrm{ft}^{2}$-year (130 gallons $/ \mathrm{m}^{2}$-year) [10].

\subsection{Maintenance and Operations}

Maintenance and operations are important aspects of high performance buildings. One of the major reasons why buildings use more energy than predicted is that equipment is left running during periods when it is not needed. A classical example is running air conditions or ventilation equipment when the building is not occupied. One way to look at how well the building is operating is to plot energy use against outside temperature. Figure 12 shows a year of data for energy use as a function of outside air temperature, for weekdays, Saturdays, and Sundays. As expected, energy use is higher at low and high temperatures on weekdays. The energy use on Saturdays is considerably lower, and lower still on Sundays, indicating that the systems are controlled during periods of low occupancy.

Figure 12. Building energy use and outside air temperature.

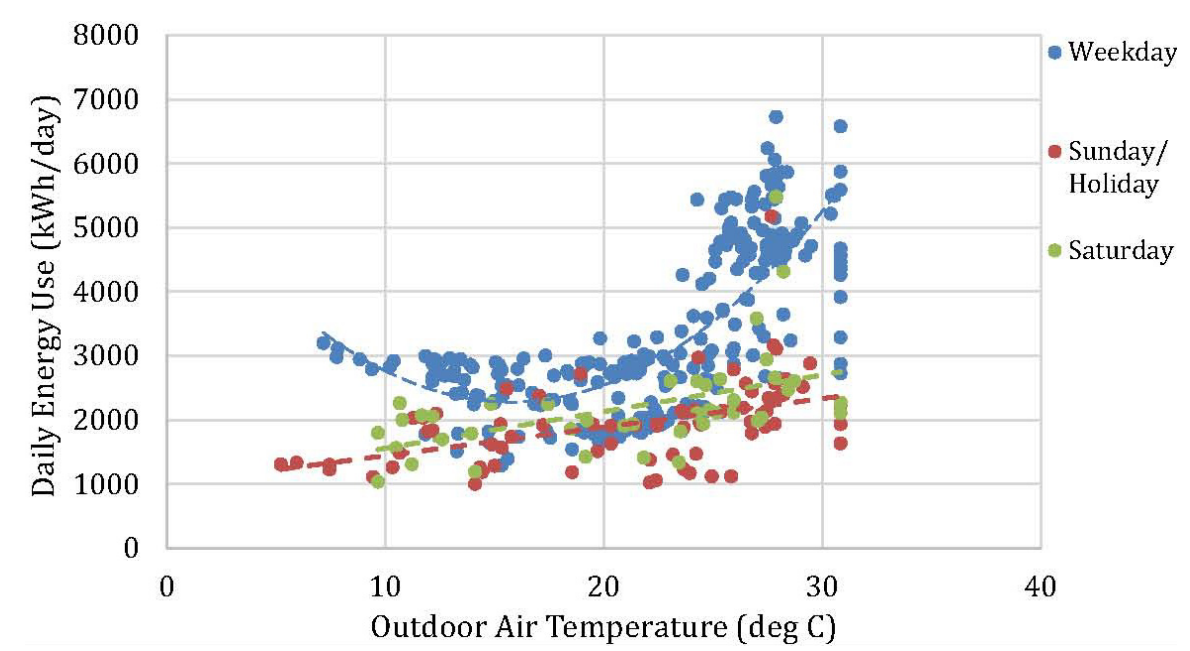

To further understand how the IRB building's energy performance correlates to weather data, we can look at the relationship between the daily energy use and the daily average outdoor air temperature (OAT). Since the outside air temperature is not very cold in the winter season, very little heating energy consumption is observed (Figure 12). The building does not have a centralized heating system, and only a few electric heaters are used in the building. Energy use does increase with OAT, but not 
significantly until the outside air temperature reaches $25^{\circ} \mathrm{C}$. During this period, mechanical cooling is rarely provided and the building is primarily conditioned by natural ventilation.

During the summer season (May to September), the building is conditioned by the water-source heat-pump system, and electricity energy consumption increases dramatically with the increase of OAT. The peak electricity use during summer season is approximately $6000 \mathrm{kWh} /$ day, twice the consumption during the natural ventilation season, when the electricity use is only about $3000 \mathrm{kWh} /$ day.

\subsection{Worker Satisfaction and Behavior}

The IBR has a staff of roughly 400 people on a daily basis. Table 6 shows the breakdown in staff by type. The majority (74\%) of the workers are regular IRB staff. Students and interns make up 7\%, property management $5 \%$, and contract staff (food service, janitorial, landscaping, security, etc.), are the remaining $14 \%$.

An important consideration for any work environment is whether comfort conditions are maintained during work hours. The Shenzhen IBR Building is an unusual building in that it allows for natural ventilation for much of the year. Workers also augment the natural ventilation with floor fans located near the window wall.

Figure 13 shows the hourly indoor temperatures and relative humidity over one year period.

Table 6. Occupant data by staff type.

\begin{tabular}{ccc}
\hline Type & Number of People & Percent \\
\hline Regular IBR staff & 308 & $74 \%$ \\
Students and intern & 30 & $7 \%$ \\
Property management staff & 21 & $5 \%$ \\
Contract staff & 60 & $14 \%$ \\
\hline Total & 419 & $100 \%$ \\
\hline
\end{tabular}

Figure 13. Shenzhen IBR indoor temperatures and relative humidity (2012).

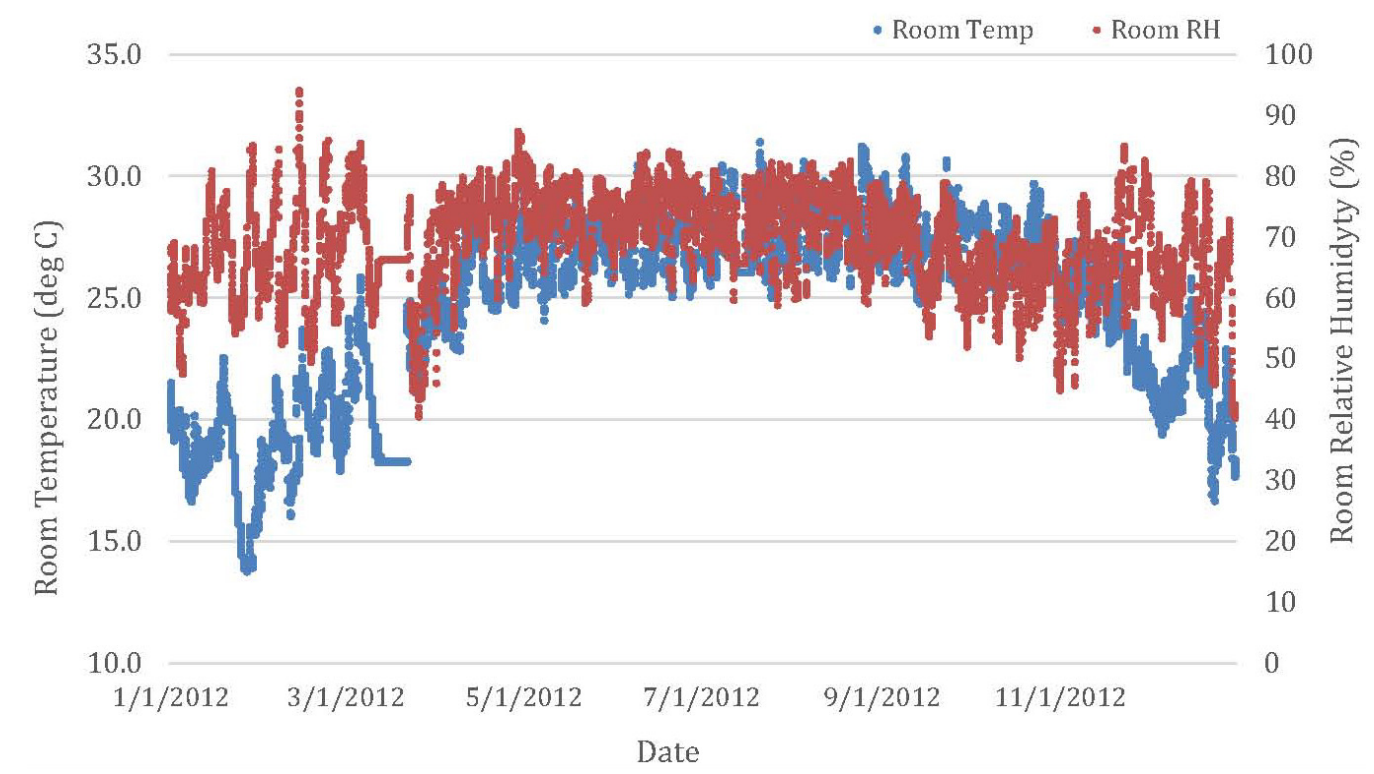


The Chinese indoor standard for comfort for summer air conditioning is $22-28{ }^{\circ} \mathrm{C}(72-82 \mathrm{~F})$ and $40 \%-80 \%$ relative humidity. For winter, the standard for temperature is $16-24{ }^{\circ} \mathrm{C}(61-75 \mathrm{~F})$. The IBR exceeded these ranges $9 \%$ of total work hours for temperature, and $3 \%$ of total work time for humidity.

\subsubsection{Occupant Surveys}

The IBR has conducted their own as well as independent surveys to evaluate the building's performance and occupants' satisfaction with the building's indoor air quality, acoustics, brightness, thermal comfort, humidity level and overall satisfaction. The occupants of the building were surveyed once a month for over a year from April 2011 through May 2011. A total of 5908 responses from the questionnaires were analyzed. Figure 14 shows the responses to the user satisfaction survey.

Based on the survey data, we see that most occupants feel satisfied with the IBR building's environment, with 94\% expressing satisfaction overall. More than three-quarters $(78 \%)$ of the occupants are satisfied with the temperature, with nearly equal numbers being either too hot (13\%) or too cold $(9 \%)$ over the course of the year.

Figure 14. Responses to the occupant survey, April-May 2011.

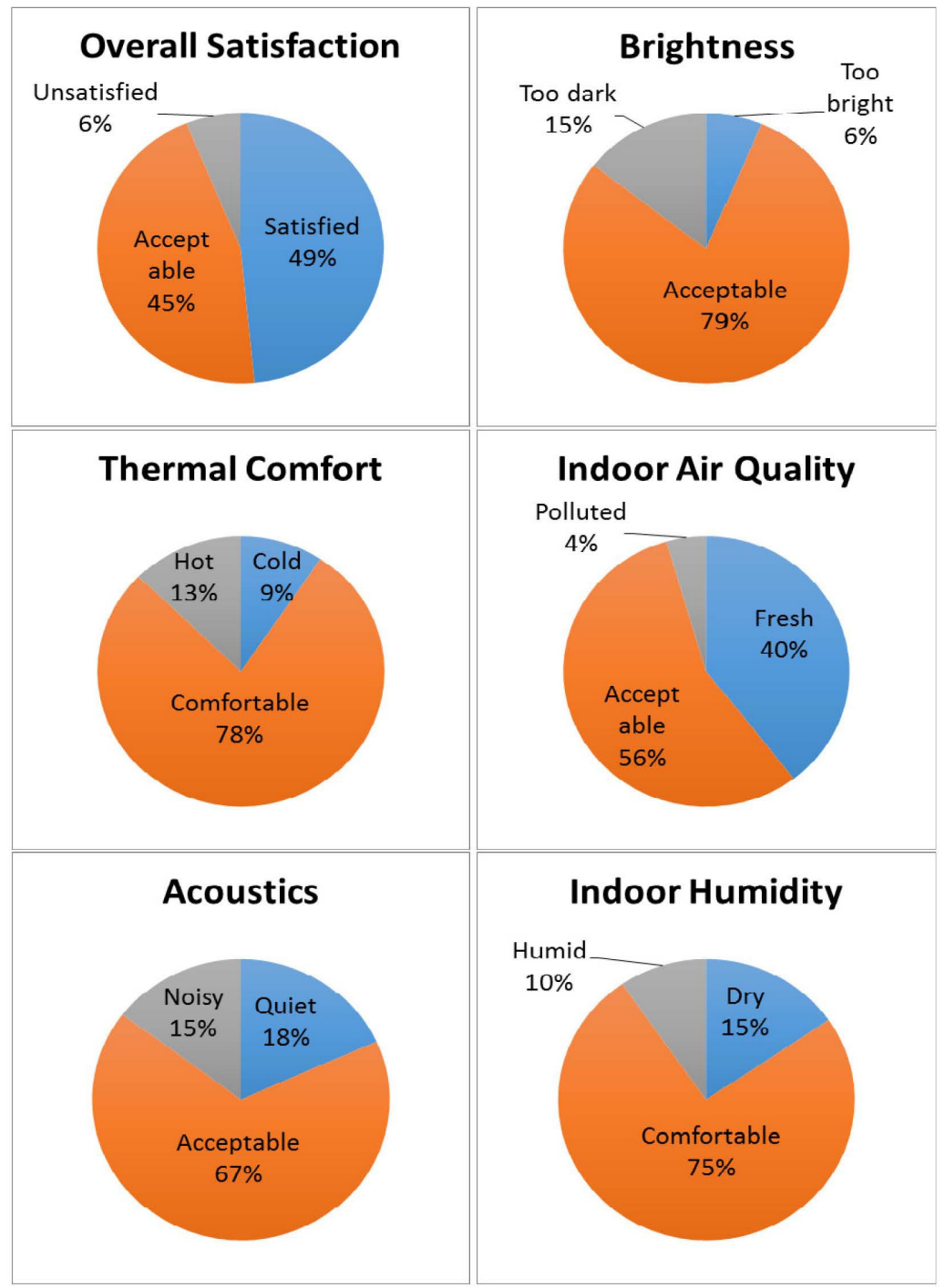


To further analyze the IRB building's thermal comfort, especially for its natural ventilation performance, we analyzed the data from the 10th floor's indoor temperature compared with the outdoor air temperature. The adaptive thermal comfort analysis is shown in Figure 15. During 2011, the building's indoor thermal conditions met with the ASHRAE 55-2010 comfort standard [11]. The majority of conditions are within $90 \%$ acceptability range (marked by the yellow dashed lines), and only a few conditions lie between $80 \%$ and $90 \%$ acceptability limits.

This agrees with the thermal comfort surveys collected for that floor, where the majority of occupants (88\%) reported that they feel comfort in the naturally ventilated conditions.

Like most open-plan office buildings, the highest dissatisfaction is with the acoustic environment. While two thirds $(67 \%)$ of the staff are satisfied with the noise level in their work space, 15\% find it too noisy, and a surprising $18 \%$ find it too quiet. The lighting environment has high acceptability (79\%), with $15 \%$ of the staff finding it too bright, and $6 \%$ finding it too dark over the course of the year. We do not know the location of the staff responding to the questionnaires, so we cannot correlate their perceptions and their location relative to the window wall.

Figure 15. Meeting "Adaptive” thermal comfort over the course of a year (2011).

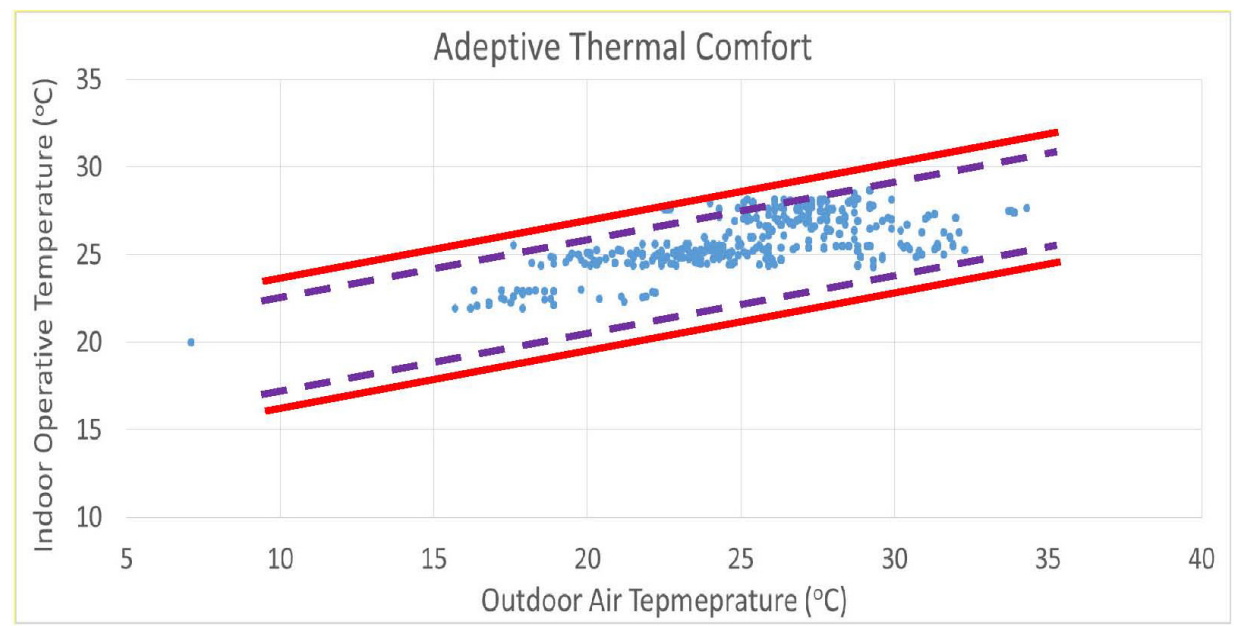

The indoor air quality and indoor humidity were also viewed as acceptable. Only 4\% perceived the indoor air quality as "polluted" which presumably meant having a detectable odor. Most of the occupants (75\%) found the indoor humidity to be comfortable, with $10 \%$ finding it too humid and $15 \%$ finding it too dry, over the course of the year. These findings supported the earlier surveys that reported similar levels of satisfaction, both overall and for the indoor environmental conditions.

\subsubsection{Indoor Air Quality Measurements}

In addition to designing for thermal comfort, the IBR was designed for high levels of indoor air quality (IAQ). Table 7 shows the test data of a sample of indoor pollutant concentrations, as well as giving the relevant Chinese and U.S. standards or guidelines. Based on the measurements shown in tests $1-3$, the indoor pollutants are very low compared to the Chinese standards for indoor air quality. 
Table 7. The test data of indoor pollutant concentration. Source: China's National Indoor Air Quality Standard GB 18883-2002 [12].

\begin{tabular}{|c|c|c|c|c|c|c|c|}
\hline \multirow{2}{*}{$\begin{array}{l}\text { Indoor Air } \\
\text { Pollutants }\end{array}$} & \multirow{2}{*}{$\begin{array}{c}\mathrm{CO} \\
\left(\mathrm{mg} / \mathrm{m}^{3}\right)\end{array}$} & \multirow{2}{*}{$\begin{array}{c}\mathrm{CO}_{2} \\
\%\end{array}$} & \multirow{2}{*}{$\begin{array}{c}\text { Formaldehyde } \\
\qquad\left(\mathrm{mg} / \mathrm{m}^{3}\right)\end{array}$} & \multicolumn{2}{|c|}{ Total VOC $\left(\mathrm{mg} / \mathrm{m}^{3}\right)$} & \multicolumn{2}{|c|}{$\operatorname{PM10}\left(\mathrm{mg} / \mathrm{m}^{3}\right)$} \\
\hline & & & & $\begin{array}{c}\text { Breathing } \\
\text { Zone }\end{array}$ & $\begin{array}{l}\text { Near the } \\
\text { Ground }\end{array}$ & $\begin{array}{c}\text { Breathing } \\
\text { Zone }\end{array}$ & $\begin{array}{l}\text { Near the } \\
\text { Ground }\end{array}$ \\
\hline China standard limit & 10 & 0.1 & 0.1 & 0.6 & - & 0.15 & - \\
\hline Test 1 & 3 & 0.045 & 0.02 & 0.029 & 0.142 & 0.058 & 0.051 \\
\hline Test 2 & 2.75 & 0.046 & 0.02 & 0.029 & - & 0.048 & - \\
\hline Test 3 & 3.25 & 0.045 & 0.02 & 0.029 & 0.142 & 0.067 & 0.051 \\
\hline
\end{tabular}

\section{Building the Future-Building the IBR in Different Climates and Regions}

One of the questions about designing a building such as the Shenzhen IBR is whether it can be replicated elsewhere. Can the process that was used by the owner and designer of the IBR be translated to other climates and cultures?

The original building, as explained earlier, was designed for the hot summer, mild winter region of south China. However, the design team also asked the question "What if the buildings were to be located in other regions of China, with different urban/rural conditions, and different climates?" Figure 16 shows the initial ideas from the IBR design team for how the same program for the building would look in different regions and climates of China.

Figure 16. IBR building designs in four different Chinese climates (Chinese text in the figure: IBR Building in different climate zones). From left to right: Urban hot summer (existing building); Urban cold winter; Rural hot dry/cold winter (above); and rural hot summer/warm winter (below).

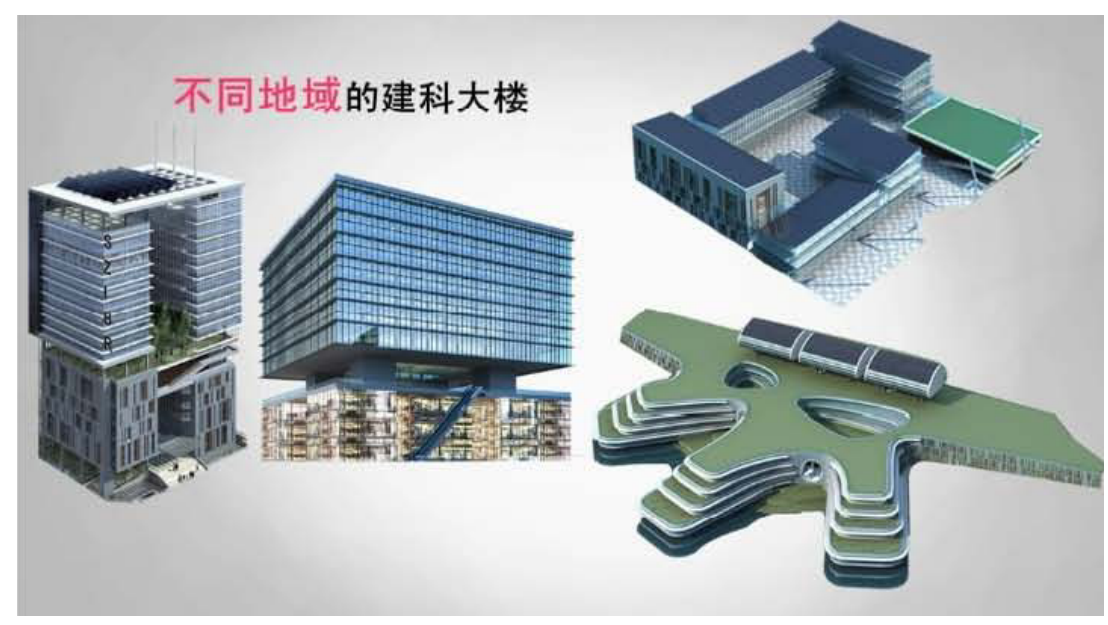

The design for the Cold climate features a building with a low surface-to-volume ratio, e.g., a cube-like form. The building has a double-glass envelope to reduce heat loss, and an interior sealed courtyard for bringing landscape to the inside of the workspace. The building is designed as a high-density urban solution.

The design for the hot climate is for a location outside the city on the South China coast, in a less-dense rural area. The building is designed to capture the steady sea breezes both for natural 
ventilation and electricity generation. Green roofs take advantage of the local high rainfall and the large roof area is used for PV panels as well. The building form maximizes envelope and interior courtyards to allow for cross ventilation and daylighting throughout.

The design for the dry rural region in the northwest of China calls for maximizing the roof surface for PV collection to take advantage of the extensive solar resource. The windows are heavily shaded by overhangs and strategic landscaping. The courtyard design allows for oasis-like outdoor spaces that are protected from the strong winds.

\section{Conclusions: A View to the Future Revisited}

We started this investigation with a profound pessimism that the current growth in the building industry in China would not address, but rather exacerbate, the daunting environmental challenges faced by the country, and by extension, the world today. What we have seen has been the growing awareness of the environmental challenges by individuals and organizations alike has led to government action, and that environmentally sensitive design is possible. While awareness alone will not slow the environmental impacts facing China, the example of the Shenzhen IBR has shown that a very-low-energy building is not only possible, but that it can provide an exemplary work environment for its users.

Recent research findings by the Energy Foundation and China Academy of Building Research reported that, "under conditions where green building practices were implemented and building energy conservation standards were strengthened and promoted, the greenhouse gas emissions of the building sector in China would witness an inflection point around 2020, and its potential for emission reductions would equal approximately one third of total building sector emissions by 2030" [2].

For this to happen we see the need for two efforts that are currently administered by two separate government agencies_-energy saving (jieneng) and emission reduction (jianpai)—will have to become fully integrated in practice. When this cooperation happens, we see the potential for the design of buildings and cities in China to make the "Green Leap Forward".

\section{Acknowledgments}

Our deepest thanks to our many friends and colleagues at the Shenzhen IBR who made this work possible. They provided warm hospitality for our visits, answered our numerous questions over the course of writing this study, and shared their extensive data and information about the building. Among the many people at IBR who helped include: Vice Dean Junyue Liu, and staff members Zongyuan Liu and Zhen Yu. We also want to thank our LBNL colleagues, starting with Mark Levine, founder of the China Energy Group, who made the initial connections with Dean Ye that led to the development of this work. Our China Energy Group colleagues Lynn Price, Nan Zhou, and Brian Heimberg all played supporting roles throughout the project, offering excellent advice and helpful direction.

This work was supported by the Shenzhen Institute of Building Research and the Assistant Secretary for Energy Efficiency and Renewable Energy, Building Technologies Office, of the U.S. Department of Energy under Contract No. DE-AC02-05CH11231. 


\section{Conflicts of Interest}

This work was co-funded by the Shenzhen Institute of Building Research to assess the performance of their building. To avoid conflict of interest, the LBNL team submitted a formal data request so that they could perform independent analyses of the raw data of the building performance.

\section{References}

1. Ye, Q. China's Commitment to a Green Agenda. Available online: http://www.mckinsey.com/ insights/asia-pacific/chinas_commitment_to_a_green_agenda?cid=china-eml-alt-mip-mck-oth-1306 (accessed on 14 June 2013).

2. Shui, B.; Li, J. Building Energy Efficiency Policies in China: Status Report; Global Buildings Performance Network: Washington, DC, USA, 2012.

3. U.S. Energy Information Administration. Commercial Buildings Energy Consumption Survey. Available online: http://www.eia.doe.gov/emeu/cbecs/contents.html (accessed on 10 May 2013).

4. Fridley, D.G.; Zheng, N.; Zhou, N. Estimating Total Energy Consumption and Emissions of China's Commercial and Office Buildings; Lawrence Berkeley National Laboratory: Berkeley, CA, USA, 2008.

5. Malone, A. Best Green Project; McGraw Hill Construction: New York, NY, USA, 2010.

6. American Society of Heating, Refrigeration and Air-Conditioning Engineers (ASHRAE). Energy Standard for Buildings except Low-Rise Residential Buildings; Standard 90.1-2010; ASHRAE: Atlanta, GA, USA, 2010.

7. Building Energy Efficiency Research Center (BEERC). Research Report on Annual Development of Building Energy Efficiency in China, 2011; Tsinghua University: Beijing, China, 2011.

8. Fowler, K.; Rauch, E.; Henderson, J.; Kora, A. Re-Assessing Green Building Performance: A Post Occupancy Evaluation of 22 GSA Buildings; Pacific Northwest National Laboratory: Richland, WA, USA, 2011.

9. International Facility Management Association (IFMA). Space and Project Management Benchmarks; IFMA: Houston, TX, USA, 2009.

10. U.S. Department of Energy, Federal Energy Management Program. Federal Water Use Indices Website. Available online: http:/www1.eere.energy.gov/femp/program/waterefficiency_ useindices.html (accessed on 10 May 2013).

11. American Society of Heating, Refrigeration and Air-Conditioning Engineers (ASHRAE). Thermal Environmental Conditions for Human Occupancy; Standard 55-2010; ASHRAE: Atlanta, GA, USA, 2010.

12. Ministry of Housing and Rural Development (MOHURD). China Indoor Air Quality Standard; GB 18883-2002; MOHURD: Beijing, China, 2002.

(C) 2013 by the authors; licensee MDPI, Basel, Switzerland. This article is an open access article distributed under the terms and conditions of the Creative Commons Attribution license (http://creativecommons.org/licenses/by/3.0/). 